\title{
METODE ISTIDLAL DAN ISTISHAB (FORMULASI METODOLOGI IJTIHAD)
}

\author{
Oleh: Umar Muhaimin
}

\begin{abstract}
$R a^{\prime} y u$ (logic) is an important aspect of ijtihad thus in ushul figh - a subject discussing the process of ijtihad - there are several method of finding the law based on logic of fuqaha (scholars), some of them are istishhab and istidlal (finding the sources). Those are two sides of a coin which are two inseparable methods of ijtihad. The source (dalil) is a material object while istidlal is a formal object. Generally, istidlal refers to finding sources either from Qur'an, Sunna (Tradition), or al Maslahah (considerations of public interest) by means of muttafaq (settled methods) such as Qur'an, Sunna (Tradition), Ijma' (consensus), Qiyas (analogy) or mukhtalaf (debatable methods) such as Mazhab ash-shahabi (fatwa of a companion), al-'urf (custom), Syar'u Man Qablana (revealed laws before Islam), istihsan (equity), istishab (presumption of continuity) or sad al-dzariah (blocking the means). Al-Syatibi classified four mind sets of understanding nash (the Text) i.e. zahiriyah (textual), batiniyat (esoteric), maknawiyat (contextual) and combination between textual and contextual.
\end{abstract}

Keyword: method, istidlal, istishab

\section{Abstrak}

Terkait dengan ijtihad, sisi $r a^{\prime} y u$ (logika-logika yang benar) adalah hal yang tidak dapat dilepaskan darinya. Karena itu, dalam Ushul Fiqh -sebuah ilmu yang "mengatur" proses ijtihad- dikenal beberapa landasan penetapan hukum yang berlandaskan pada penggunaan kemampuan ra'yu para fuqaha, salah satunya adalah istishhab. Selain itu ada yang bisa dipakai, yakni istidlal (penemuan dalil).

Istishhab dan istidlal (penemuan dalil) merupakan dua metodologi ijtihad, yang bagaikan dua sisi mata uang. Artinya 
ia merupakan dua metodologi ijtihad yang bertolak belakang, antara memilih Istishhab atau istidlal.

Dalil merupakan obyek materiil, dan istidlal merupakan obyek formil. Istidlal secara umum berarti pengambilan dalil, baik menggunakan dalil Qur`an, as-Sunnah, maupun al-Maslahah, dengan menggunakan metode yang muttafaq yakni Qur`an, as-Sunnah, Ijma' dan Qiyas, atau metode yang masih mukhtalaf yakni Mazhab as-Shahabi, al-`Urf, dan Syar`u Man Qablana, , istihsan, istihlah maupun sad al-dzariah.

Al-Syatibi mengelompokkan empat macam bentuk pola pikir dalam memenuhi maksud nas (al-Syatibi, tt : 391-392). Yaitu pola pikir Zahiriyah (tekstualis), Batiniyat (Esoteris), Maknawiyat (kontekstualis), dan Gabungan antara tekstualitas dan kontekstualitas.http://www.iaitribakti.ac.id/index.php?

option=com_content\&task=view\&id=79\&Itemid=104 -_edn18

\section{A. Pendahuluan}

Syariat Islam adalah penutup semua risalah samawiyah, yang membawa petunjuk dan tuntunan Allah untuk umat manusia dalam wujudnya yang lengkap dan final. Itulah sebabnya, dengan posisi seperti ini, Allah pun mewujudkan format Syariat Islam sebagai syariat yang abadi dan komperhensif.

Hal itu dibuktikan dengan adanya prinsip-prinsip dan kaidah-kaidah hukum yang ada dalam Islam yang membuatnya dapat memberikan jawaban terhadap hajat dan kebutuhan manusia yang berubah dari waktu ke waktu, seiring dengan perkembangan zaman. Secara kongkrit hal itu ditunjukkan dengan adanya dua hal penting dalam hukum Islam yaitu; (1) nas-nas yang menetapkan hukum-hukum yang tak akan berubah sepanjang zaman dan (2) pembukaan jalan bagi para mujtahid untuk melakukan ijtihad dalam hal-hal yang tidak dijelaskan secara sharih dalam nas-nas tersebut.

Ijtihad adalah mencurahkan segenap kemampuan berfikir dalam menggali dan merumuskan syar'i yang bersifat dhanni dengan menggunakan metode tertentu yang dilakukan oleh yang berkompeten baik secara metodologis maupun permasalahan. Posisi ijtihad bukan sebagai sumber hukum 
melainkan sebagai metode penetapan hukum, sedangkan fungsi ijtihad adalah sebagai metode untuk merumuskan ketetapan-ketetapan hukum yang belum terumuskan dalam AlQur'an dan As-Sunnah.

Ruang Lingkup Ijtihad meliputi : (1). Masalah-masalah yang terdapat dalam dalil-dalil dhanni. (2). Masalah-masalah yang secara eksplisit tidak terdapat dalam Al-qur'an dan AsSunnah.

Terkait dengan ijtihad, sisi ra'yu (logika-logika yang benar) adalah hal yang tidak dapat dilepaskan darinya. Karena itu, dalam Ushul Fiqh -sebuah ilmu yang "mengatur" proses ijtihad- dikenal beberapa landasan penetapan hukum yang berlandaskan pada penggunaan kemampuan $r a^{\prime} y u$ para fuqaha, salah satunya adalah istishhab. Selain itu ada yang bisa dipakai, yakni istidlal (penemuan dalil).

Istishhab dan istidlal (penemuan dalil) merupakan dua metodologi ijtihad, yang bagaikan dua sisi mata uang. Artinya ia merupakan dua metodologi ijtihad yang bertolak belakang, antara memilih Istishhab atau istidlal.

Makalah ini mencoba menjelaskan dua metodologi ijtihad tersebut, meliputi pengertian, pendapat para fuqaha tentang kedudukannya dan cara kerja keduanya.

\section{B. Dalil dan Istidlal}

\section{Pengertian Dalil dan Istidlal}

Dalil adalah isim fa'il dari kata dalla yang berarti petunjuk. Sedangkan Istidlal menurut bahasa berarti pengambilan dalil. Dalil merupakan obyek materiil, dan istidlal merupakan obyek formil. Dalam Ushul fiqh, pembagian dalil bermacam-macam. Ada ulama yang membagi dalil menjadi enam: al-Qur`an, as-Sunnah, alMaslahah, Mazhab as-Shahabi, al-`Urf, dan Syar`u Man Qablana. Sedangkan Qiyas dan Ijma' masih rancu bila dimasukkan sebagai dalil (obyek materiil) tapi lebih tepat dimasukkan ke dalam istidlal (obyek formil), sebab ia mempergunakan al-Qur’an dan as-Sunnah sebagai dalilnya. Demikian pula dengan istihsan, istislah dan sad aldzariah lebih tepat dimasukkan ke dalam istidlal (obyek formil), sebab ia menjadikan al-maslahah sebagai dalilnya. 
Istidlal secara umum berarti pengambilan dalil, baik menggunakan dalil Qur`an, as-Sunnah, maupun alMaslahah, dengan menggunakan metode yang muttafaq yakni Qur`an, as-Sunnah, Ijma' dan Qiyas, atau metode yang masih mukhtalaf yakni Mazhab as-Shahabi, al-`Urf, dan Syar`u Man Qablana, , istihsan, istihlah maupun sad al-dzariah.

\section{Dasar Hukum Istidlal}

Allah memerintahkan untuk mengembalikan segala urusan dan permasalahan kepada al-Qur'an \& Sunnah, sebagaimana firman Allah :

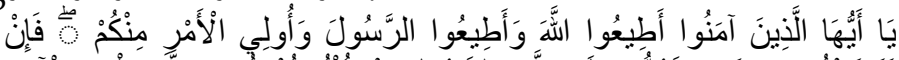

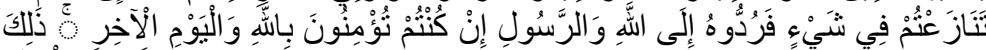
خَيْرِ وَأَحْسَنْ تَأُوِيلًا

"Hai orang-orang yang beriman, taatilah Allah dan taatilah Rasul(-Nya), dan ulil amri di antara kamu. Kemudian jika kamu berlainan pendapat tentang sesuatu, maka kembalikanlah ia kepada Allah (Alquran) dan Rasul (sunnahnya), jika kamu benar-benar beriman kepada Allah dan hari kemudian. Yang demikian itu lebih utama (bagimu) dan lebih baik akibatnya. (QS. 4:59).

Imam Ibnu Katsir berkata bahwa ini perintah Allah untuk mengembalikan semua permasalahan yang diperselisihkan baik pada masalah dasar-dasar agama atau cabangnya kepada Al-Qur'an dan sunnah" (Ibnu Katsir, tt : I/ 338). Mafhumnya, menunjukkan larangan untuk menyandarkan permasalahan hanya kepada akal semata.

Dari penjelasan tersebut dapat dipahami bahwa dalam struktur ilmu figh yang pertama adalah sumber hukum (Masadir al-Ahkam) http://www.iaitribakti.ac.id/index.php?option $=$ com_content\&task=view \&id=79\&Itemid=104 -_edn12 yaitu wahyu yang meliputi al-Qur'an dan al-Sunnah dan kedua adalah dalil Hukum (adillah al-Ahkam http://www.iaitribakti.ac.id/index.php?option=com_content\&task=view \&id=79\&Itemid=104 - edn13 yang merupakan beberapa metode para ahli hukum (mujtahid) dalam menggali dan menemukan hukum Islam dari sumbernya yakni al- 
Qur'an atau as-Sunnah yang biasa disebut dengan Ijtihad ,Istinbat, istidla http://www.iaitribakti.ac.id/index.php?option=com_content\&task=view \&id=79\&Itemid=104 - _edn14.

\section{Cara Kerja Memahami Maksud Nas}

Al Syatibi (tt : 264) ketika menjelaskan firman Allah SWT : "Adapun orang-orang yang dalam hatinya condong kepada kesesatan, maka mereka mengikuti sebagian ayat-ayat yang mutasyabihat untuk menimbulkan fitnah dan untuk mencari-cari penakwilannya." (Qs. Ali 'Imraan [3]: 7) menjelaskan bahwa ayat ini mencakup dua bagian yang keduanya menjadi sumber untuk berjalan di atas jalan yang benar atau berjalan di atas jalan yang salah.

Ketika dikhususkan bagi orang-orang yang di dalam hatinya terdapat kecondongan terhadap kesesatan dengan mengikuti perkara yang mutasyabihat, maka pengkhususan tersebut menjadi dalil bahwa orang-orang yang mendalam ilmunya tidak mengikutinya karena mereka hanya mengikuti ayat-ayat yang muhkam, yaitu ummul kitab dan kandungannya.

Jadi, setiap dalil khusus atau dalil umum yang telah dijelaskan oleh sebagian besar hukum syariat, pasti dalil yang benar, dan selain dalil itu adalah dalil yang salah. Sebab antara dalil yang benar dengan dalil yang salah tidak terdapat perantara dalil lain yang dapat dijadikan sandaran, karena jika terdapat dalil yang ketiga maka pasti akan dijelaskan dengan nas ayat Al Qur'an.

Selanjutnya al Syatibi ( $t t$ : 598-601) menjelaskan bahwa di dalam nas terdapat makna yang munasib, di mana hukum diikat padanya. Bentuknya ada tiga macam, yaitu :

a. Makna Munasib yang Syariat menyatakan dan menguatkan bahwa munasib itu diterima. Di sini tidak ada permasalahan dengan ke-shahih-annya dan tidak ada perbedaan dalam memberlakukannya. Jika tidak disikapi demikian maka justru melawan syariat, seperti syariat qishas untuk menjaga jiwa, anggota badan, dan lain-lain.

b. Makna munasib yang ditolak oleh syariat. Di sini tidak ada jalan untuk menerimanya, sebab munasabah tidak 
mengharuskan (menghasilkan) adanya hukum dengan dirinya sendiri, bukan seperti yang dipakai oleh madzhab ahlutt-tahsinul aql (menganggap baik secara logika akal). Semestinya jika maknanya sudah nampak secara zhahir dan kita memahami bahwa syariat mengambilnya sebagai I'tibar yang mengharuskan adanya hukum, maka pada saat itu kita menerimanya.

c. Makna Munasib yang didiamkan oleh syahid-syahid (penguat-penguat) yang khusus. Tidak menguatkan i'tibar terhadapnya dan meniadakannya. Makna Munasib ini ada dua bentuk, yaitu :

1) Tidak disebutkan nash yang menyepakati makna itu, seperti ta'lil (alasan) dilarangnya membunuh untuk mendapatkan warisan, perlakuan yang ada berlawanan dengan maksud, jika kita andaikan tidak ada nash yang tersebut secara cocok, maka alasan ini tidak ada dalam pengaturan syariat, baik dengan fardh maupun dengan mula'amah, untuk mendapatkan jenis yang bisa dianggap. Jadi, tidak dibenarkan untuk menggunakannya sebagai ta'lil, dan juga tidak bisa membangun hukum di atasnya. Yang seperti ini adalah tasyri' dari orang yang mengatakannya, maka tidak mungkin dapat diterima.

2) Sesuai dengan tindakan atau pengaturan syariat, yaitu ada suatu jenis yang di-i'tibari oleh syariat secara umum terhadap makna itu tanpa ada dalil tertentu. Inilah istidlal yang mursal, yang disebut dengan al maslahat al mursalah.

Sebenarnya dalam al-Qur'an ataupun as-Sunnah sudah disebutkan mengenai tata tertib urutan pemakaian beberapa sumber dan dalil hukum yang ada. Untuk itu dapat diambil pemahaman bahwa dalam mencari fiqh seorang mujtahid akan memahami nas al-Qur'an atau asSunnah, kemudian jika tidak ada dalam keduanya mereka akan berijtihad dengan berbagai metode yang beragam mulai dengan ijma', qiyas yang dalam kategori 
adillah

al-ahkam http://www.iaitribakti.ac.id/index.php?option $=$ com content\&task=view \&id=79\&Itemid=104 - _edn17 Untuk itu muncullah istilah Ijtihad, Istidlal, istinbat, istiqra' dan sebagainya dalam rangka mencari pemahaman status hukum dari sebuah persoalan yang ditemui sehingga pada akhirnya akan menghasilkan hukum.

Hanya saja kajian cara kerja semacam itu antar mujtahid juga berbeda. Hal ini dikarenakan kualitas penggunaan ra'yu dalam rangka menjawab persoalanpersolan yang muncul, atau sarana apa yang dapat dipakai untuk mengetahui hukum tersebut.

Al-Syatibi mengelompokkan empat macam bentuk pola pikir dalam memenuhi maksud nas (al-Syatibi, tt : 391-392). Yaitu pola pikir Zahiriyah (tekstualis), Batiniyat (Esoteris), Maknawiyat (kontekstualis), dan Gabungan antara tekstualitas dan kontekstualitas http://www.iaitribakti.ac.id/index.php?option=com_content\&task=view \&id=79\&Itemid=104 - _edn18 Penjelasannya adalah sebagai berikut;

\section{a. Pola pikir Zahiriyat.}

Mazhab ini dipelopori oleh Dawud bin Ali Khalaf al-Asbahani al-Zahiri. Ia lahir di Kufah tahun $202 \mathrm{H}$ dan Wafat di Bagdad tahun $270 \mathrm{H}$, dalam usia 68 tahun (Abu Zahrah, $\mathrm{tt}$ 111) http://www.iaitribakti.ac.id/index.php?option $=$ com_content\&task=view \&id=79\&Itemid=104 _ _ edn19 Menurut pola pikir kaum tekstualis maksud syara' hanya dapat diketahui dari lafadz teks sebagaimana apa yang tersurat. Alasannya bahwa maksud syari'ah yang tertuang dalam redaksi nas menurut mereka masih misterius tanpa ada penjelasan dari nas itu sendiri http://www.iaitribakti.ac.id/index.php?option=com_content\&task=view \&id=79\&Itemid=104 - _edn20 Untuk itu melalui firmanfirman yang tertuang itulah kita dapat memahami nas. Berhubung kaum zahiriyat hanya berpegang pada lahirnya nas, maka tidak memerlukan bantuan pemahaman di luar nas dalam menetapkan hukum. Menurut Golongan ini pengetahuan fiqih cukup didapatkan dari al-Qur'an dan as-Sunnah tanpa ada dalil 
lain selain kedua sumber tersebut. Sehingga seandainya tidak didapatkan sebuah hukum suatu persoalan waqi'iyah dari keduanya, maka masalah waqi'iyah akan dimauqufkan. Atau ada kecenderungan permisif, yakni seandainya al-Qur'an dan al-sunah tidak menyebutkan hukum sesuatu, maka hukumnya adalah boleh (ibahah) (al-Syatibi, $\mathrm{tt}:$ 392).

\section{b. Pola Batiniyat.}

Pola pikir batiniyat ini, dalam menetapkan hukum tidak seperti kaum zahiriyat yang menangkap makna lahir dari nas, bukan pula memahami makna yang terkandung dalam lafal (kontekstual), tetapi pola pikir yang dipakai oleh sekte Syiah batiniyah http://www.iaitribakti.ac.id/index.php?option=com_content\&task=view \&id=79\&Itemid=104 - edn21 Mereka hanya mempercayai imamnya yang ma'shum -kebal salah dan kebal dosa- apa kata imam itulah kebenaran http://www.iai-

tribakti.ac.id/index.php?option $=$ com_content\&task=view \&id=79\&Itemid=104 - edn22 Golongan ini dinamai Batiniyat karena mempunyai pendirian setiap yang lahir ada batinnya, dan setiap yang turun dalam arti wahyu ada ta'wilnya http://www.iaitribakti.ac.id/index.php?option $=$ com_content\&task $=$ view \&id=79\&Itemid=104 edn2 3 http://www.iaitribakti.ac.id/index.php?option=com_content\&task=view \&id=79\&Itemid=104 - _edn23 Pola pikir ini sangat liberal dan tidak menggunakan kaidah umum sebagaimana yang terdapat dalam kajian ilmu ushul al-figh. Seperti dalam penafsiran al-Qur'an begitu liberal dan batiniyat, tidak ada aturan apapun kecuali kehendak merekahttp://www.iai-

tribakti.ac.id/index.php?option=com_content\&task=view \&id=79\&Itemid=104 - _edn24 Kata Kafir mereka artikan orang yang ingkar kepada ali bin Abi Thalib, Taharat diartikan mengambil sesuatu yang diizinkan oleh imam, puasa berarti tidak membuka rahasiahttp://www.iaitribakti.ac.id/index.php?option=com_content\&task=view \&id=79\&Itemid=104 -_edn25 Untuk itu menurut mereka 
segala persoalan hukum dapat ditemukan dalam ketiga sumber hukum yaitu al-qur'an, al-Sunnah dan ketiga adalah fatwa imam mereka yang ma'shum (al-Syatibi, tt : 392).

\section{c. Pola pikir kontekstual.}

Pola pikir kontekstual menurut al-Syatibi adalah kelompok yang melakukan qiyas dan analogi. Kelompok ini lebih memprioritaskan makna lafaz dari pada lafaz itu sendiri. Doktrin yang mereka ajukan dalam memahami nas adalah mencari makna di balik teks selagi hasil yang diperoleh tidak bertentangan dengan teks-teks tersebut, kecuali teks-teks tersebut bersifat mutlak (Khalaf, 1401 : 192).http://www.iai-

tribakti.ac.id/index.php?option $=$ com_content\&task=view \&id=79\&Itemid=104 - _edn27 Sedangkan yang dimaksud mutlak lafaz adalah lafaz yang menunjukkan kesatuan makna yang utuh. Jika ada pertentangan teks nas dengan makna teks atas dasar nazariyat, kelompok kontekstualisme akan mengutamakan makna hasil penalaran dengan alasan demi tegaknya kemaslahatan, atau mencari makna baru karena bukan merupakan kewajiban bagi mujtahid untuk bertahan pada pengambilan maksud nas secara tekstual/http://www.iaitribakti.ac.id/index.php?option=com_content\&task=view \&id=79\&Itemid=104 - _edn28 Mereka mengembangkan paham bahwa hukum Allah itu ditegakkan karena adanya illat atau kemaslahatan bagi umat manusia (alSyatibi, tt : 392).

\section{d. Gabungan antara tekstualis dan kontekstualis.}

Al-Syatibi menyatakan bahwa golongan pola pikir gabungan antara tekstualis dan kontekstualis merupakan golongan yang benar-benar matang intelektualitasnya (rasikhun) dalam mengetahui maksud syara' . Ia sendiri menyatakan bahwa dirinya masuk golongan ini. Mereka menggabungkan antara yang tersurat dan tersirat dari makna teks adalah tidak bertentangan http://www.iaitribakti.ac.id/index.php?option $=$ com_content\&task $=$ view 
\&id=79\&Itemid=104 dikembangkan kelompok ini sama dengan kelompok kontekstualis yang salah satu wujud nyatanya adalah almutaamiqin fi al-qiyas dan zahiriyat dengan pendirian bahwa syari' (Allah dan Rasul) di dalam mensyari'tkan hukum, apakah berhubungan dengan masalah adat atau ibadat, masing-masing mempunyai maksud yang asli (asliyat) dan maksud yang mendampinginya (taba'iyat) (al-Syatibi, tt $\quad$ : $\quad$ 392) http://www.iaitribakti.ac.id/index.php?option $=$ com_content\&task $=$ view \&id=79\&Itemid=104 -_edn30

Dengan beberapa tipologi berpikir tersebut dapat dipahami bahwa pola pikir tekstual (zahiriyat) lebih menekankan pemahaman teks tanpa berpaling kepada rasionalitas dengan perangkat akalnya. Berarti Wahyu sebagai sumber informasi satu-satunya. Di samping zahiriyat adalah kaum batiniyat yang menggunakan perasaan (zauq al-hawas) untuk memperoleh ilmu. Pola pikir kontekstual lebih cenderung kepada reasoning sehingga ilmu menurut mereka lebih dipahami dari makna yang tersirat (implisit) daripada yang tersurat. Sedangkan pola pikir keempat dalam memahami nas harus ada sinergisitas dalam memahami makna teks dan konteks.

\section{Istishab}

\section{Definisi Istishhab}

Istishhab secara bahasa adalah menyertakan, membawa serta dan tidak melepaskan sesuatu, (Manzhur, 1410 : term sha-hi-ba) Seperti kata:

artinya: aku membuat buku itu ikut serta bersamaku dalam perjalananku.

Adapun secara terminologi, ada beberapa definisi yang disebutkan oleh ulama Ushul Fiqh, di antaranya adalah:

a. Definisi al-Asnawy (w. $772 \mathrm{H}$ ) yang menyatakan bahwa "(Istishhab) adalah penetapan (keberlakukan) hukum terhadap suatu perkara di masa selanjutnya atas dasar bahwa hukum itu telah berlaku 
sebelumnya, karena tidak adanya suatu hal yang mengharuskan terjadinya perubahan (hukum tersebut)" (al Asnawy, tt : 3/131).

b. Sementara al-Qarafy (w. $486 \mathrm{H}$ ) -seorang ulama Malikiyah- mendefinisikan istishhab sebagai "keyakinan bahwa keberadaan sesuatu di masa lalu dan sekarang itu berkonsekwensi bahwa ia tetap ada (eksis) sekarang atau di masa datang" (al-Qarafy, 1393 :199).

Definisi ini menunjukkan bahwa istishhab sesungguhnya adalah penetapan hukum suatu perkara baik itu berupa hukum ataupun benda- di masa kini ataupun mendatang berdasarkan apa yang telah ditetapkan atau berlaku sebelumnya. Seperti ketika kita menetapkan bahwa si A adalah pemilik rumah atau mobil ini -entah itu melalui proses jual-beli atau pewarisan-, maka selama kita tidak menemukan ada dalil atau bukti yang mengubah kepemilikan tersebut, kita tetap berkeyakinan dan menetapkan bahwa si A-lah pemilik rumah atau mobil tersebut hingga sekarang atau nanti. Dengan kata lain, istishhab adalah melanjutkan pemberlakuan hukum di masa sebelumnya hingga ke masa kini atau nanti (Isma'il, 1415 : 2/103-104).

\section{Kedudukan Istishhab}

Banyak ulama yang menjelaskan bahwa secara hirarki ijtihad, istishhab termasuk dalil atau pegangan yang terakhir bagi seorang mujtahid setelah ia tidak menemukan dalil dari al-Qur'an, al-Sunnah, ijma' atau qiyas. AlSyaukany misalnya mengutip pandangan seorang ulama yang mengatakan:

"Ia (istishhab) adalah putaran terakhir dalam berfatwa. Jika seorang mufti ditanya tentang suatu masalah, maka ia harus mencari hukumnya dalam al-Qur'an, kemudian al-Sunnah, lalu ijma', kemudian qiyas. Bila ia tidak menemukan (hukumnya di sana), maka ia pun (boleh) menetapkan hukumnya dengan 'menarik pemberlakuan hukum yang lalu di masa sekarang' (istishhab al-hal). Jika ia ragu akan tidak berlakunya hukum itu, maka prinsip asalnya adalah bahwa hukum itu tetap berlaku..." (Syaukany, $1414: 237$ ). 
Dalam menyikapi apakah istishhab dapat dijadikan sebagai dalil dalam proses penetapan hukum, para ulama Ushul Fiqih terbagi dalam 3 pendapat :

Pendapat pertama, bahwa istishhab adalah dalil (hujjah) dalam penetapan ataupun penafian sebuah hukum. Pendapat ini didukung oleh Jumhur ulama dari kalangan Malikiyah, Hanabilah, mayoritas ulama Syafi'iyah dan sebagian Hanafiyah.

Di antara argumentasi mereka dalam mendukung pendapat ini adalah:

1. Firman Allah:

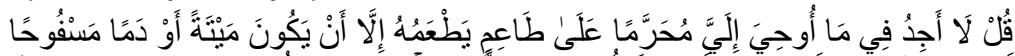

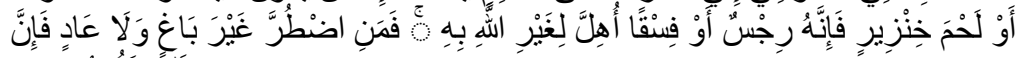

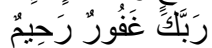

"Katakanlah (wahai Muhammad): 'Aku tidak menemukan dalam apa yang diwahyukan kepadaku sesuatu yang diharamkan untuk dimakan kecuali jika adalah bangkai, atau darah yang mengalir, atau daging babi..." (al-An'am:145)

Ayat ini -menurut mereka- menunjukkan bahwa prinsip asalnya adalah segala sesuatu itu hukumnya mubah hingga datangnya dalil yang menunjukkan pengharamannya. Hal ini ditunjukkan dengan Firman Allah: "Katakanlah (wahai Muhammad): 'Aku tidak menemukan..." . Pernyataan ini menunjukkan bahwa ketika tidak ada ketentuan baru, maka ketentuan lamalah yang berlaku (Isma'il, $1415: 2 / 111)$.

2. Rasulullah saw bersabda:

"Sesungguhnya syetan mendatangi salah seorang dari kalian (dalam shalatnya) lalu mengatakan: 'Engkau telah berhadats! Engkau telah berhadats!' Maka (jika demikian), janganlah ia meninggalkan shalatnya hingga ia mendengarkan suara atau mencium bau." (HR. Ahmad).

Dalam hadits ini, Rasulullah saw memerintahkan kita untuk tetap memberlakukan kondisi awal kita pada saat mulai mengerjakan shalat (yaitu dalam keadaan suci) bila syetan membisikkan keraguan padanya bahwa wudhu'nya telah batal. Bahkan Rasulullah melarangnya untuk meninggalkan shalatnya hingga menemukan bukti 
bahwa wudhu'nya telah batal; yaitu mendengar suara atau mencium bau. Inilah hakikat istishhab it

3. Ijma'.

Para pendukung pendapat ini menyatakan bahwa ada beberapa masalah fiqih yang telah ditetapkan melalui ijma' atas dasar istishhab. Di antaranya adalah bahwa para ulama telah berijma' bahwa jika seseorang ragu apakah ia sudah bersuci, maka ia tidak boleh melakukan shalat, karena dalam kondisi seperti ini ia harus merujuk pada hukum asal bahwa ia belum bersuci. Ini berbeda jika ragu apakah wudhu'nya sudah batal atau belum, maka dalam kasus ini ia harus berpegang pada keadaan sebelumnya bahwa ia telah bersuci dan kesucian itu belum batal (Ibid, 2/112).

4. Dalil 'aqli.

Di antara dalil 'aqli atau logika yang digunakan oleh pendukung pendapat ini adalah:

- Penetapan sebuah hukum pada masa sebelumnya dan tidak adanya faktor yang menghapus hukum tersebut membuat dugaan keberlakuan hukum tersebut sangat kuat (al-zhann al-rajih). Dalam syariat Islam, sebuah dugaan kuat (al-zhann al-rajih) adalah hujjah, maka dengan demikian istishhab adalah hujjah pula.

- Ketika hukum tersebut ditetapkan pada masa sebelumnya atas keyakinan, maka penghapusan hukum itu pun harus didasarkan atas keyakinan, berdasarkan kaidah al-yaqin la yazulu/yuzalu bi alsyakk.

Pendapat kedua, bahwa istishhab tidak dapat dijadikan sebagai hujjah secara mutlak, baik dalam menetapkan hukum ataupun menafikannya. Ini adalah pendapat mayoritas ulama Hanafiyah (Badsyah, tt : 4/176).

Di antara dalil dan pegangan mereka adalah :

1. Menggunakan istishhab berarti melakukan sesuatu dengan tanpa landasan dalil. Dan setiap pengamalan yang tidak dilandasi dalil adalah batil. Maka itu berarti bahwa istishhab adalah sesuatu yang batil. 
2. Istishhab akan menyebabkan terjadinya pertentangan antara dalil, dan apapun yang menyebabkan hal itu maka ia adalah batil. Ini adalah karena jika seseorang boleh menetapkan suatu hukum atas dasar istishhab, maka yang lain pun bisa saja menetapkan hukum yang bertentangan dengan itu atas dasar istishhab pula.

Pendapat ketiga, bahwa istishhab adalah hujjah pada saat membantah orang yang memandang terjadinya perubahan hukum yang lalu -atau yang dikenal dengan bara'ah al-dzimmah- dan tidak dapat sebagai hujjah untuk menetapkan suatu hukum baru. Pendapat ini dipegangi oleh mayoritas ulama Hanafiyah belakangan dan sebagian Malikiyah (Abd al-'Azis, 1394 : 3/390, Syaukany, 1414 : 238).

Dalam hal ini yang menjadi alasan mereka membedakan kedua hal ini adalah karena dalil syar'i hanya menetapkan hukum itu di masa sebelumnya, dan itu tidak bisa dijadikan sebagai landasan untuk menetapkan hukum baru di masa selanjutnya.

Dengan melihat dalil-dalil yang dipaparkan oleh ketiga pendapat ini, nampak jelas bahwa dalil pendapat pertama sebenarnya jauh lebih kuat dari dua pendapat lainnya. Istishhab adalah sesuatu yang fitrawi dalam diri manusia, yaitu bahwa jika tidak ada suatu bukti atau dalil yang mengubah hukum atau label pada sesuatu menjadi hukum lain, maka yang berlaku dalam pandangan mereka adalah tetap hukum yang pertama.

Karena itu fuqaha pun menyepakati kaidah al-yaqin la yazulu bi al-syakk -termasuk yang mengingkari istishhab-, dan kaidah inilah yang sesungguhnya menjadi salah satu landasan kuat istishhab ini. Itulah sebabnya, para qadhi pun memberlakukan prinsip yang sama dalam keputusan peradilan mereka. Dalam hubungan suami-istri misalnya, jika tidak ada bukti bahwa hubungan itu telah putus, maka sang qadhi tetap memutuskan berlakunya hubungan itu seperti yang telah ada sebelumnya (Khalaf, 1401 :152-152).

\section{Jenis-jenis Istishhab}

Ulama menyebutkan jenis-jenis berikut: 
a. Istishhab hukum asal atas sesuatu saat tidak ditemukan dalil lain yang menjelaskannya; yaitu mubah jika ia bermanfaat dan haram jika ia membawa mudharat -dengan perbedaan pendapat yang masyhur di kalangan para ulama tentangnya; yaitu apakah hukum asal sesuatu itu adalah mubah atau haram.

Salah satu contohnya adalah jenis makanan dan minuman yang tidak ditemukan dalil yang menjelaskan hukumnya dalam al-Qur'an dan al-Sunnah, atau dalil lainnya seperti ijma' dan qiyas (Isma'il, $1415: 2 / 105$ ).

Untuk macam ini, para ulama berbeda pendapat dalam 3 mazhab:

Pendapat pertama, bahwa hukum asal segala sesuatu adalah mubah, hingga adanya dalil yang menetapkan atau mengubahnya. Pendapat ini dipegangi oleh Jumhur Mu'tazilah, sebagian ulama Hanafiyah, Syafi'iyah dan Zhahiriyah http://abulmiqdad.multiply.com/journal/compose _ftnref12 (al Gazali, $1417: 3 / 132$ )

Dalil-dalil mereka antara lain adalah ayat-ayat alQur'an yang zhahirnya menunjukkan bahwa pada dasarnya segala sesuatu itu mubah, seperti :

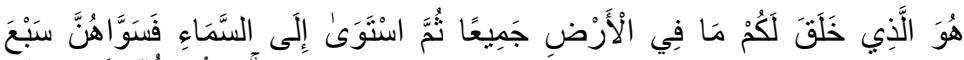

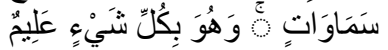

"Dia-lah yang menciptakan untuk kalian segala sesuatu yang ada di bumi." (al-Baqarah:29)

Ayat ini menunjukkan bahwa semua yang ada di bumi ini untuk dimanfaatkan oleh manusia, dan hal itu tidak mungkin dimanfaatkan kecuali jika hukumnya mubah.

Juga firman-Nya:

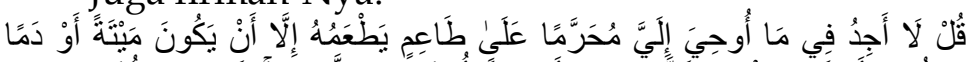

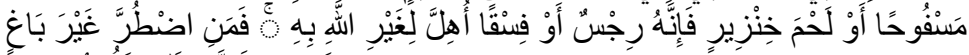

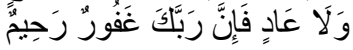

"Katakanlah (wahai Muhammad): 'Aku tidak menemukan dalam apa yang diwahyukan padaku sesuatu yang diharamkan kepada seseorang yang memakannya kecuali 
jika ia berupa bangkai, darah yang mengalir, atau daging babi..." (al-An'am:145)

Ayat ini menunjukkan bahwa apa yang tidak disebutkan di dalamnya tidak diharamkan karena tidak adanya dalil yang menunjukkan itu, dan itu semuanya karena hukum asalnya adalah mubah.

Pendapat kedua, bahwa hukum asal sesuatu itu adalah haram, hingga ada dalil syara' yang menetapkan atau mengubahnya. Pendapat ini dipegangi oleh sebagian Ahl al-Hadits dan Mu'tazilah Baghdad (al Gazali, $1417: 3 / 132$ ).

Alasan mereka adalah karena yang berhak untuk menetapkan syariat dan hukum adalah Allah saja. Maka jika kita membolehkan sesuatu yang tidak ada nashnya, maka berarti kita telah melakukan apa yang seharusnya menjadi hak prerogatif Sang pembuat syariat tanpa seizin-Nya. Ini tidak dibenarkan sama sekali.

Pendapat ketiga, bahwa hukum asal segala sesuatu yang bermanfaat adalah mubah, sementara yang membawa mudharat adalah haram. Pendapat ini dipegangi oleh Jumhur ulama. Mereka menggunakan dalil pendapat yang pertama untuk menguatkan bahwa hukum asal sesuatu yang bermanfaat adalah mubah, dan dalil pendapat yang kedua untuk menegaskan bahwa hukum asal sesuatu yang membawa mudharat adalah haram (Isma'il, $1415: 2 / 107$ ).

Di samping itu, untuk menegaskan sisi kedua dari pendapat ini, mereka juga berlandaskan pada hadits:

$$
\text { لَا ضَرَرَ وَلَا ضِرِرَارَ }
$$

"Tidak ada kemudharatan dan tidak (boleh) memberi mudharat (dalam Islam)." (HR. Ibnu Majah dan AlDaraquthni dengan sanad yang hasan).

b. Istishhab al-Bara'ah al-Ashliyah, atau bahwa hukum asalnya seseorang itu terlepas dan bebas dari beban dan tanggungan apapun, hingga datangnya dalil atau bukti yang membebankan ia untuk melakukan atau mempertanggungjawabkan sesuatu (Ibid, 2/108). 
Sebagai contoh misalnya adalah bahwa kita tidak diwajibkan untuk melakukan shalat fardhu yang keenam dalam sehari semalam -setelah menunaikan shalat lima waktu-, karena tidak adanya dalil yang membebankan hal itu.

Demikian pula -misalnya- jika ada seseorang yang menuduh bahwa orang lain berhutang padanya, sementara ia tidak bisa mendatangkan bukti terhadap tuduhan itu, maka orang yang tertuduh dalam hal ini tetap berada dalam posisi bebas dari hutang atas dasar al-Bara'ah al-Ashliyah ini.

c. Istishhab hukum yang ditetapkan oleh ijma' pada saat berhadapan dengan masalah yang masih diperselisihkan (Ibid, 2/109).

Salah satu contohnya adalah bahwa para ulama telah berijma' akan batalnya shalat seorang yang bertayammum karena tidak menemukan air saat ia menemukan air sebelum shalatnya. Adapun jika ia melihat air pada saat sedang mengerjakan shalatnya; apakah shalatnya juga batal atas dasar istishhab dengan ijma' tersebut, atau shalat tetap sah dan ia boleh tetap melanjutkannya?

Imam Abu Hanifah dan beberapa ulama lain seperti al-Ghazaly dan Ibnu Qudamah- berpendapat bahwa dalam masalah ini istishhab dengan ijma' terdahulu tidak dapat dijadikan landasan, karena berbedanya kondisi yang disebutkan dalam ijma'. Oleh sebab itu, ia harus berwudlu kembali.

Sementara Imam al-Syafi'i dan Abu Tsaur berpendapat bahwa istishhab ijma' ini dapat dijadikan sebagai hujjah hingga ada dalil lain yang mengubahnya. Oleh sebab itu, shalatnya tetap sah atas dasar istishhab kondisi awalnya yaitu ketiadaan air untuk berwudhu.

\section{Pengaruh Istishhab dalam Persoalan-persoalan Furu'iyah}

Berikut ini adalah beberapa contoh persoalan furu'iyah yang termasuk dalam kategori tersebut:

a. Pewarisan Orang yang Hilang (al-Mafqud) 
Orang yang hilang (al-mafqud) adalah orang yang menghilang dari keluarganya hingga beberapa waktu lamanya, dimana tidak ada bukti yang dapat digunakan untuk membuktikan apakah ia masih hidup atau sudah mati.

Dalam kasus ini, para ulama berbeda pendapat antara memvonis ia masih hidup sehingga peninggalannya tidak boleh dibagikan kepada ahli warisnya dan ia tetap berhak mendapatkan warisan jika ada kerabatnya yang meninggal saat kehilangannya; dan memvonis ia telah meninggal sehingga peninggalannya dapat dibagikan kepada ahli warisnya. Dalam hal ini, ada tiga pendapat di kalangan para ulama:

Pendapat pertama, bahwa ia tetap dianggap hidup -baik untuk urusan yang terkait dengan dirinya maupun yang terkait dengan orang lain-. Karena itu semua hukum yang berlaku untuk orang yang masih hidup tetap diberlakukan padanya; hartanya tidak diwariskan, istrinya tidak boleh dinikahi, dan wadi'ah yang ia titipkan pada orang lain tidak boleh diambil. Pendapat ini dipegangi oleh Imam Malik dan al-Syafi'i (al Syafi'i, tt : 4/4). Hujjah mereka adalah bahwa orang yang hilang itu sebelum ia hilang ia tetap dihukumi sebagai orang yang hidup. Karena itu hukum ini wajib diistishhabkan hingga sekarang sampai ada bukti yang mengubah hukum tersebut.

Pendapat kedua, ia dianggap hidup terkait dengan hak dirinya sendiri. Pendapat ini dilandaskan pada pandangan bahwa istishhab hanya dapat digunakan untuk mendukung hukum yang telah ada sebelumnya, tapi bukan untuk menetapkan hukum baru (Isma'il, $1415: 2 / 118$ ).

Pendapat ketiga, ia dianggap hidup baik terkait dengan hak dirinya maupun hak orang lain selama 4 tahun sejak hilangnya. Jika 4 tahun telah berlalu, maka ia dianggap telah meninggal terkait dengan hak dirinya maupun hak orang lain; hartanya dibagi, ia tidak lagi mewarisi dari kerabatnya yang meninggal dan istrinya dapat dinikahi. Pendapat ini dipegangi oleh Imam 
Ahmad bin Hanbal (Ibn Qudamah, tt : 6/389). Alasan pembatasan jangka waktu 4 tahun adalah pengqiyasan jika ia meninggalkan istrinya selama 4 tahun, sehingga menurut pendapat ini- jika ia meninggalkan istrinya selama itu, maka hakim dapat memisahkan keduanya dan istrinya dapat dinikahi setelah masa iddah sejak pemisahan itu berakhir.

\section{Pembahasan}

Dalil merupakan obyek materiil, dan istidlal merupakan obyek formil. Istidlal secara umum berarti pengambilan dalil, baik menggunakan dalil Qur`an, as-Sunnah, maupun alMaslahah, dengan menggunakan metode yang muttafaq yakni Qur'an, as-Sunnah, Ijma' dan Qiyas, atau metode yang masih mukhtalaf yakni Mazhab as-Shahabi, al-'Urf, dan Syar`u Man Qablana, , istihsan, istihlah maupun sad al-dzariah.

Dalam al-Qur'an ataupun al-Sunnah sudah disebutkan mengenai tertib urutan pemakaian beberapa sumber dan dalil hukum yang ada. Untuk itu dapat diambil pemahaman bahwa dalam mencari fiqh seorang mujtahid akan memahami nas alQur'an atau al-Sunnah, kemudian jika tidak ada dalam keduanya mereka akan berijtihad dengan berbagai metode yang beragam mulai dengan ijma', qiyas yang dalam kategori adillah al-ahkam,http://www.iaitribakti.ac.id/index.php?option=com_content\&task=view\&id= 79\&Itemid=104 - _edn17 Untuk itu munculah istilah Ijtihad, Istidlal, istinbat, istigra' dan sebagainya dalam rangka mencari pemahaman status hukum dari sebuah persoalan yang ditemui sehingga pada akhirnya akan menghasilkan hukum.

Dalam melakukan ijtihad, metode pertama yang dipakai adalah istidlal, baru kemudian ketika tidak ditemukan dalil sebagai rujukannya, dipakailah metode istishab. Oleh karena itu banyak ulama yang menjelaskan bahwa secara hirarki ijtihad, istishhab termasuk dalil atau pegangan yang terakhir bagi seorang mujtahid setelah ia tidak menemukan dalil dari alQur'an, al-Sunnah, ijma' atau qiyas.

Istishhab adalah sesuatu yang fitrawi dalam diri manusia, yaitu bahwa jika tidak ada suatu bukti atau dalil yang mengubah hukum atau label pada sesuatu menjadi hukum lain, 
maka yang berlaku dalam pandangan mereka adalah tetap hukum yang pertama.

Karena itu fuqaha pun menyepakati kaidah al-yaqin la yazulu bi al-syakk -termasuk yang mengingkari istishhab-, dan kaidah inilah yang sesungguhnya menjadi salah satu landasan kuat istishhab ini. Itulah sebabnya, para qadhi pun memberlakukan prinsip yang sama dalam keputusan peradilan mereka. Dalam hubungan suami-istri misalnya, jika tidak ada bukti bahwa hubungan itu telah putus, maka sang qadhi tetap memutuskan berlakunya hubungan itu seperti yang telah ada sebelumnya.

\section{E. Simpulan}

Ijtihad antara lain mempunyai dua metodologi yang bisa dipakai, yakni istidlal (penemuan dalil) dan istishab. Dua metode ini merupakan sesuatu yang bertolak belakang. Artinya Mujtahid pada awalnya harus memilih Istidlal dan ketika tidak mungkin, maka memakai Istishab..

Istishhab merupakan salah satu pijakan dan metode penggalian serta penyimpulan hukum dalam Islam. Dari uraian tersebut dapat disimpulkan bahwa istishhab sebenarnya dapat digunakan sebagai landasan hukum. Meskipun dalam beberapa bentuk istishhab terdapat perbedaan pendapat di kalangan ulama. Namun hal itu tidak menafikan kedudukan argumentatif istishhab dalam Fiqh Islam. 


\section{DAFTAR PUSTAKA}

'Abd al-'Azis, 'Ala al-Din ibn ibn Ahmad al-Bukhary, 1394 H., Kasyf al-Asrar 'an Ushul al-Bazdawy. Beirut. : Dar alKitab al-'Araby.

Al-Asnawy, 'Abd al-Rahim ibn Hasan al-Syafi'i, t.t., Nihayah alSaul fi Syarh Minhaj al-Ushul..Kairo : Al-Mathba'ah alSalafiyah.

Al-Ghazaly, Abu Hamid Muhammad ibn Muhammad, 1417 H., Al-Mustashfa fi 'Ilm al-Ushul. Beirut. : Dar al-Kutub al'Ilmiyah.

Al-Syafi'i, Muhammad ibn Idris, t.t., Al-Umm. Beirut : Dar alFikr.

Al-Syatibi, Abi Ishaq Ibrahim Al-Lahmi, t.t., Al-Muwafaqat Fi Usul Al-Shari'at, Beirut : Dar Al-Ma'rifat. t.t., al I'tisham, Beirut: Dar Al-Ma'rifat.

Badsyah, Muhammad Amir, t.t., Taisir al-Tahrir. Beirut : Dar alFikr.

Ibn Katsir, t.t., Tafsir Ibnu Katsir, Beirut ; Dar al Fikr.

Ibn Manzhur, Abu al-Fadhl Muhammad ibn Mukrim, 1410 H. Lisan al-'Arab.. Beirut. Beirut.: Dar Shadir, Cetakan pertama.

Ibn Qudamah, 'Abdullah ibn Ahmad, t.t., Al-Mughny. Maktabah al-Riyadh al-Haditsah.

Isma'il, Sya'ban Muhammad, 1415 H., Ushul Figh al-Muyassar, Kairo : Dar al-Kitab al-Jami'iy, Cetakan pertama.

Khallaf, 'Abd al-Wahhab, $1401 \mathrm{H}$, Ilm Ushul al-Figh. Kuwait : Dar al-Qalam, Cetakan keempat belas.

Syaukany, Muhammad ibn 'Ali al-, 1414 H., Irsyad al-Fuhul ila Tahqiq al-Haq min 'Ilm al-Ushul, Beirut. : Dar al-Kutub al-'Ilmiyyah. Cetakan pertama. 